\title{
Methane and soil and plant community respiration from wetlands, Kejimkujik National Park, Nova Scotia: Measurements, predictions, and climatic change
}

\author{
Moshe Dalva and Timothy R. Moore \\ McGill University, Montréal, Québec, Canada \\ Paul Arp \\ University of New Brunswick, Fredericton, New Brunswick, Canada \\ Thomas A. Clair \\ Environment Canada - Atlantic Region, Sackville, New Brunswick, Canada
}

\begin{abstract}
A static, dark chamber technique was used weekly from mid-July to midNovember in 1995 and biweekly from mid-May to late November in 1996, to measure methane $\left(\mathrm{CH}_{4}\right)$ flux and soil and plant community respiration of $\mathrm{CO}_{2}$ from 36 sites in two wetlands in Kejimkujik National Park in south-central Nova Scotia, Canada. Overall mean fluxes of $\mathrm{CH}_{4}$ were $43 \mathrm{mg} \mathrm{m}^{-2} \mathrm{~d}^{-1}$ in 1995 and $20 \mathrm{mg} \mathrm{m}^{-2} \mathrm{~d}^{-1}$ in 1996 . Respiration rates were $5.1 \mathrm{~g} \mathrm{CO}_{2} \mathrm{~m}^{-2} \mathrm{~d}^{-1}$ in 1995 and $3.2 \mathrm{~g} \mathrm{CO}_{2} \mathrm{~m}^{-2} \mathrm{~d}^{-1}$ in 1996 . Fluxes of $\mathrm{CH}_{4}$ and $\mathrm{CO}_{2}$ were related to microtopography and ecological grouping, depth to water table, and air and peat temperatures. Edge and hummock sites showed the lowest $\mathrm{CH}_{4}$ flux and the highest respiration rate, while pools showed the highest $\mathrm{CH}_{4}$ and lowest respiration rate. Gas emissions displayed a strong seasonal pattern with highest values occurring during the summer (June to August) and with a marked reduction in late fall. Depth to water table and air temperature explained 34 to $43 \%$ of the variance in $\mathrm{CH}_{4}$ flux and respiration from the sites over the 2 years $(n=666$ to 824$)$. We developed algorithms relating the daily mean flux of $\mathrm{CH}_{4}$ and respiration from the wetlands to an aspatial soil moisture, water table, and temperature model (ForHyM2) applied to the wetland basins. We then applied this model to calculated May to October fluxes of $\mathrm{CH}_{4}$ and $\mathrm{CO}_{2}$ from 1966 to 1998 . We estimated that $\mathrm{CH}_{4}$ fluxes ranged from 2.8 to $7.4 \mathrm{~g} \mathrm{~m}^{-2}$, with a mean of $3.7 \mathrm{~g} \mathrm{~m}^{-2}$ and a standard deviation of $1.2 \mathrm{~g} \mathrm{~m}^{-2}$ over the 1966-1998 period. Respiration estimates ranged from 0.60 to $1.16 \mathrm{~kg}$ $\mathrm{CO}_{2} \mathrm{~m}^{-2}$, with a mean of $0.74 \mathrm{~kg} \mathrm{CO}_{2} \mathrm{~m}^{-2}$ and a standard deviation of $0.11 \mathrm{~kg} \mathrm{CO}_{2} \mathrm{~m}^{-2}$. Application of a $2 \mathrm{xCO}_{2}$ General Circulation Model scenario to temperature and precipitation for this part of eastern Canada resulted in increases of growing season $\mathrm{CH}_{4}$ emissions from 4.7 to $11.4 \mathrm{~g} \mathrm{~m}^{-2}$ and respiration from 0.77 to $1.32 \mathrm{~kg} \mathrm{CO}_{2} \mathrm{~m}^{-2}$.
\end{abstract}

\section{Introduction}

Wetlands occupy $1.3 \times 10^{6} \mathrm{~km}^{2}$ of the Canadian landmass and play an important role in the global carbon cycle as a source of methane $\left(\mathrm{CH}_{4}\right)$ and a sink of carbon dioxide $\left(\mathrm{CO}_{2}\right)$ [Fung et al., 1991; Gorham, 1991]. In general, there is a large degree of spatial, temporal interseasonal and intraseasonal variability in the flux of these gases between wetlands and the atmosphere. These fluxes are also sensitive to temperature and precipitation and should therefore change with changing climate [Cao et al., 1998; Moore et al., 1998].

$\mathrm{CH}_{4}$ emission rates from northern peatlands can vary from 0 to over $50 \mathrm{~g} \mathrm{~m}^{-2} \mathrm{yr}^{-1}$. The primary controls on these rates are water table position, thermal regime, substrate, and vegetation cover [e.g., Bubier and Moore, 1994]. Rates of $\mathrm{CH}_{4}$ emission have been established in many regions of Canada, often with an overall similarity between rates in relation to depth of water table [see Moore et al., 1998]. Thus far however, no rates have

\section{Copyright 2001 by the American Geophysical Union.}

Paper number 2000JD900500.

0148-0227/01/2000JD900500\$09.00 been reported from the wet northeastern region of North America, where peatlands cover almost $7 \times 10^{3} \mathrm{~km}^{2}$.

Large year-to-year variations in $\mathrm{CH}_{4}$ emissions have been measured from wetlands [e.g., Alm et al., 1999; Waddington and Roulet, 1996]. For example, Roulet et al. [1992] established relationships between $\mathrm{CH}_{4}$ emissions, peat temperature and depth to water table, and used predicted changes in precipitation and temperature from a $2 \mathrm{xCO}_{2}$ General Circulation Model (GCM) scenario for Canada to calculate expected changes in $\mathrm{CH}_{4}$ emissions for northern peatlands. Cao et al. [1998] estimated changes in $\mathrm{CH}_{4}$ emissions from wetlands in relation to climate change at the global scale.

Less attention has been paid to $\mathrm{CO}_{2}$ respiration rates from northern peatland soils and plant communities, which generally range from 0.2 to $2 \mathrm{~kg} \mathrm{CO}_{2} \mathrm{~m}^{-2} \mathrm{yr}^{-1}$ [e.g. Raich and Potter, 1995; Silvola et al., 1996]. In principle, the same environmental controls affect both respiration and $\mathrm{CH}_{4}$ emission rates, namely, peat temperature, peat type, and vegetation cover, and depth to water table, [e.g., Moore and Dalva, 1993; Silvola et al., 1996].

We studied $\mathrm{CH}_{4}$ flux and soil and plant community respiration from soils in two wetlands in the Pine Marten Brook watershed, in Kejimkujik National Park, located in southwestem Nova Scotia, Canada. We related these emissions to local microtopography and plant communities, variations in depth to water table, and air and peat thermal regimes in order to 


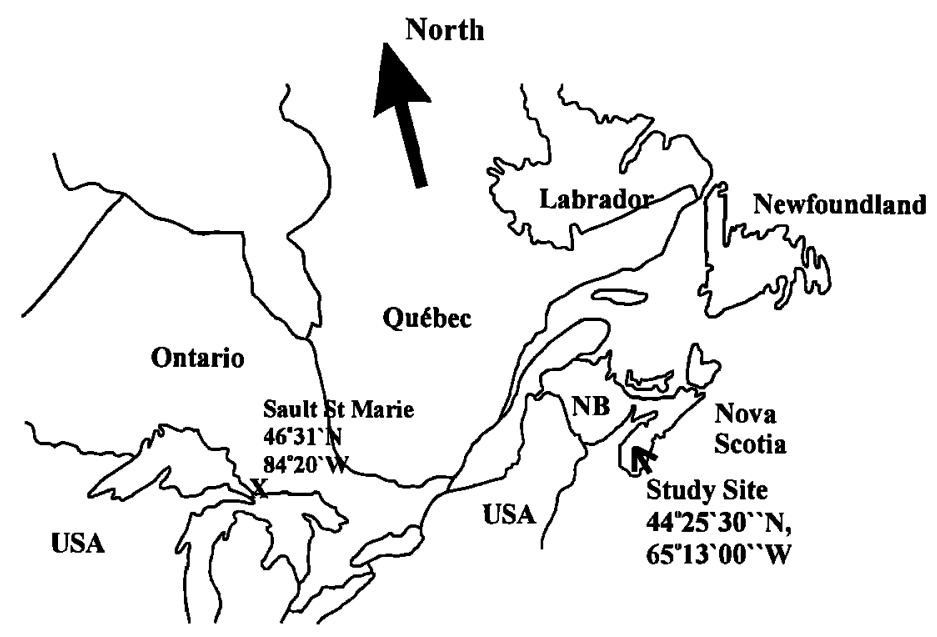

Figure 1. Location of study area.

derive an understanding of the main controlling factors of gas fluxes in these wet, temperate peatlands. We also linked wetland fluxes to a regional, climate-driven, aspatial forest soil temperature and moisture model to produce a model linking climate variables to gas fluxes over the whole wetland. We applied climate data from the past 33 years (1966-1998) to this model to predict the interannual variation in gas emissions We then used temperature and precipitation inputs predicted by the Canadian Climate Centre GCMII $2 \mathrm{xCO}_{2}$ model for the specific climate change conditions of Nova Scotia [Boer et al., 1992] and applied these to the climatic record from 1992 to 1998. Using these data in the gas emission model allowed us to assess potential $\mathrm{CH}_{4}$ and soil and plant community respiration fluxes from the wetlands under a new climate regime.

\section{Study Site}

Kejimkujik National Park is located approximately $60 \mathrm{~km}$ from both the Atlantic Ocean and the Bay of Fundy in eastern Canada (Figure 1). Mean annual precipitation (1967-1993) is $1403 \mathrm{~mm}$, of which approximately $57 \%$ occurs from November to May (Table 1). Annual average temperature is $6.3^{\circ} \mathrm{C}$, while the May to November average is $12.2^{\circ} \mathrm{C}$.

Two wetlands in the Park's Pine Marten Brook watershed were selected for this work. The upper wetland, $1.4 \mathrm{ha}$ in size drains into the lower which is 2.1 ha [Allen et al., 1992]. Most plant communities in the wetlands were dominated by Sphagnum spp. which accounted for approximately $50 \%$ of total ground cover. Major species were Sphagnum centrale, $S$.

Table 1. Monthly Mean Precipitation and Air Temperatures for Kejimkujik National Park, Nova Scotia; from May to November 1995 and 1996, along with the 26 Year Average

\begin{tabular}{|c|c|c|c|c|c|c|}
\hline & \multicolumn{3}{|c|}{ Precipitation, mm } & \multicolumn{3}{|c|}{ Temperature, ${ }^{\circ} \mathrm{C}$} \\
\hline & 1995 & 1996 & $\begin{array}{l}26 \\
\mathrm{yr} \\
\mathrm{av}\end{array}$ & 1995 & 1996 & $\begin{array}{c}26 \\
\mathrm{yr} \\
\mathrm{av}\end{array}$ \\
\hline May & 67 & 131 & 98 & 9.6 & 9.4 & 10.8 \\
\hline June & 79 & 84 & 90 & 16.7 & 15.9 & 15.6 \\
\hline July & 71 & 161 & 102 & 20.1 & 18.2 & 18.4 \\
\hline August & 47 & 38 & 94 & 18.1 & 18.6 & 17.6 \\
\hline September & 53 & 309 & 97 & 13.9 & 14.3 & 12.8 \\
\hline October & 119 & 103 & 116 & 11.1 & 9.9 & 7.6 \\
\hline November & 187 & 80 & 154 & 3.2 & 2.4 & 2.4 \\
\hline $\begin{array}{c}\text { May- } \\
\text { November }\end{array}$ & 623 & 906 & 751 & 13.2 & 12.7 & 12.2 \\
\hline
\end{tabular}

imbricatum, $S$. fallax, $S$. flexuosum, $S$. magellanicum, and $S$. torreyanum. The remainder of the groundcover comprised of Calamogrostis canadensis, Dulichium arndinaceum and Juncus effusus. The overstory consisted of alder (Alnus spp.), balsam fir (Abies balsamea), and white spruce (Picea glauca). Sampling sites were not selected to provide an estimate of average conditions but to take into account the various types of wetland plant communities found. These also usually reflected differences in average depth to water table. Peat depths in the upper bog were $>1 \mathrm{~m}$, while those in the lower one were between 30 and $100 \mathrm{~cm}$. Both bogs have a few isolated hummocks or mounds along the edges.

\section{Materials and Methods}

Thirty six sampling sites with permanently installed $25 \mathrm{~cm}$ diameter collars were established along eight transects containing variations in microtopography and hydrological conditions. Most replicate sampling sites were placed along stream bank and pool areas as these generally showed the highest and most variable gas fluxes, particularly for $\mathrm{CH}_{4}$. A system of boardwalks was constructed in the second year of the study to all sampling sites to allow access without disturbing the peat surface. Fluxes were measured by determining changes in headspace concentration of the gases within an 18 $\mathrm{L}$ polycarbonate chamber placed on the collar. The chamber was covered with aluminum foil to minimize heating. $\mathrm{CO}_{2}$ emission rates therefore reflected total heterotrophic and autotrophic emissions from soil and plants.

Midmorning $\mathrm{CO}_{2}$ and $\mathrm{CH}_{4}$ measurements were made weekly from mid-July to mid-November 1995 and biweekly from early May to mid-November 1996. Chamber gas samples were collected every $5 \mathrm{~min}$. for a period of $20 \mathrm{~min}$. in 1995 , and six samples over $25 \mathrm{~min}$. in 1996. Air samples were transferred to evacuated, $10 \mathrm{~mL}$ aluminum-seal head space vials and shipped to McGill University for immediate $\mathrm{CO}_{2}$ and $\mathrm{CH}_{4}$ analyses.

Water table depth relative to the peat surface was measured in $3.8 \mathrm{~cm}$ diameter PVC tubes located within $1 \mathrm{~m}$ of the collars. Peat temperature was determined in 1996 by installing four temperature probes containing thermistors at $5,10,15$, 20 , and $50 \mathrm{~cm}$ depths. Resistance readings were converted to temperature from calibrations supplied by the manufacturer and verified in the lab. Two probes were installed in each bog, with one in a dry or edge area and the other in a pool or bank area. In data analyses, temperatures obtained from the probes in the dry areas were used for hummock and edge collars and those in the wet areas for stream banks or pools.

$\mathrm{CO}_{2}$ and $\mathrm{CH}_{4}$ concentrations were determined using a Shimadzu Mini-2 flame ionization detector and a Shimadzu 
MTN-1 Methanizer, respectively, within 48 to 72 hours of collection. Three to four point calibrations were constructed using gas standards of $2.57,50.8,211$ and $2037 \mathrm{ppmv} \mathrm{CH}_{4}$, and 383,1986 , and 10000 ppmv $\mathrm{CO}_{2}$. The precision of calibrated standards (coefficient of variation of 12 to 15 injections per concentration) generally ranged from 0.7 to

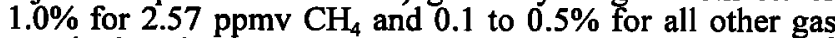
standards. The detection limit for $\mathrm{CH}_{4}$ fluxes was $0.8 \mathrm{mg} \mathrm{m}^{-2}$ $\mathrm{d}^{-1}$ and $0.17 \mathrm{~g} \mathrm{~m}^{-2} \mathrm{~d}^{-1}$ for $\mathrm{CO}_{2}$. Concentration changes in the chambers over the $20-25 \mathrm{~min}$. sampling intervals were converted to fluxes following corrections for chamber volume, area, and exposure time. Only rates from those regressions that were significant at $90 \%$ confidence interval are reported $(n=$ $\left.3, r^{2}>0.97 ; n=4, r^{2}>0.80 ; n=5, r^{2}>0.70 ; n=6, r^{2}>0.65\right)$.

Prior to boardwalk construction in late August 1995, many measurements had to be rejected due to local disturbance, particularly in the Upper Bog. Rejection rates for $1995 \mathrm{CH}_{4}$ and $\mathrm{CO}_{2}$ flux data were $>40 \%$ and $25 \%$, respectively. After boardwalk construction, data rejection rates decreased to $21 \%$ and $18 \%$ for $\mathrm{CH}_{4}$ and $\mathrm{CO}_{2}$ fluxes, respectively.

In order to assess wetland conditions controlling gas fluxes at individual sites, we used multiple regression analysis with depth to water table, plant community and air or peat temperature as independent variables, and log-transformed the $\mathrm{CH}_{4}$ and $\mathrm{CO}_{2}$ fluxes following an examination of the initial residuals plots. In this analysis, spring was defined from the beginning of the sampling period to June 21; summer from June 21 to September 21, and fall from September 21 to November 21. Snow-free seasonal fluxes were derived using temporally integrated means and a season length of 230 days.

To estimate wetland-wide changes in respiration and $\mathrm{CH}_{4}$ emission, we used the aspatial Forest Hydrology Model 2 (ForHyM2) [Meng et al., 1995] to evaluate the year-round soil moisture and temperature conditions in the soils immediately surrounding the wetlands and the average level of the water table as it would change in the wetlands from day to day. This model simulates all salient water and heat flows through a forest and/or a forest catchment with daily resolution. Model compartments address canopy layer, organic surface layer, soil layers (A, B, C, and subsoil), and snowpack. Flows address interception, evapotranspiration, throughfall, snow melt, soil infiltration, percolation, runoff, interflow, water table fluctuations, freezing and thawing, heat conduction, and net radiational fluxes (inputs/outputs), year round.

This model does not address the spatial distribution of soil heat and moisture. Modeled water table fluctuations, for example, are not confined to a particular position in the landscape but represent expected variations about an arbitrarily chosen reference level which may change from year to year depending on soil compaction and regional water table levels. In the model, water table fluctuations are directly related to fluctuations in subsoil moisture content. Here volume fluctuations in subsoil moisture estimates are spread over the available pore space. Due to the downslope of wetlands, fluctuations in water table for the uplands correlate directly into water table fluctuations in the wetlands. Similarly, calculations for upland soil temperatures are assumed to correlate directly to wetland peat temperatures.

Model input was restricted to daily meteorological data (snow, rain, mean daily air temperature, daily solar radiation) and to average soil and canopy conditions. An Environment Canada weather station, located $500 \mathrm{~m}$ from Pine Martin Brook, provided weather data from 1966 to 1998 . Modeled regional soil moisture and temperature $(\mathrm{O}, \mathrm{A}, \mathrm{B}$, and $\mathrm{C}$ layers) and average water table levels were then regressed against wetland $\mathrm{CH}_{4}$ and $\mathrm{CO}_{2}$ fluxes averaged over all sites each week. This provided a regional estimate of fluxes as opposed to site by site descriptions. In so doing, regional upland soil conditions were used as proxies for estimating the corresponding moisture and temperature variations within the wetlands. The resulting regression equations were subsequently built into the ForHyM 2 model to calculate daily $\mathrm{CH}_{4}$ and $\mathrm{CO}_{2}$ fluxes as outlined.

Model output was used in two ways. First, we extracted daily weather data for the May to November period from the local weather station for the period 1966 to 1998 and used these records to estimate regional water table and then the cumulative annual growing season fluxes for $\mathrm{CH}_{4}$ and $\mathrm{CO}_{2}$ fluxes for each year. Second, we isolated the 1992-98 daily weather data and modified these by the monthly changes predicted by the Canadian Climate Centre General Circulation Model II (CCC GCMII) [Boer et al., 1992] for the $2 \mathrm{xCO}_{2}$ scenario for the period of May to November. For this part of Nova Scotia the model predicted temperature changes of $+3^{\circ}$ for May, August, September, October, and November, and $+4^{\circ}$ for June and July. Precipitation was predicted to decrease by $-5 \%$ in May, August and November, and $15 \%$ in June, and no change was predicted for July, September, and October.

\section{Results and Discussion}

\subsection{Site Conditions, $1995-1996$}

Precipitation during the 1995 sampling period (July to November) was $85 \%$ of the 26 year mean (Table 1) and was lower than average during all months of the sampling period, except for November. Precipitation in 1996 was $21 \%$ higher than the long-term mean, with greater July and September and lower August values. A number of tropical storms affected the region in 1996, especially in September, when one event produced $117 \mathrm{~mm}$ of rainfall. Mean monthly temperature in both years were similar to the long-term means, reaching $18^{\circ}$ to $20^{\circ} \mathrm{C}$ in July, and between $2^{\circ}$ and $3^{\circ} \mathrm{C}$ in November. $A$ consequence of the intra-annual differences in precipitation was a difference in depth to water table. In 1995, depth to water table ranged from -2 to $-30 \mathrm{~cm}$ and in 1996 from +11 to $-25 \mathrm{~cm}$. All but two of the jar collars in the Upper Bog submerged or had the water table within $6 \mathrm{~cm}$ of the surface during the 1996 sampling season.

\section{2. $\mathrm{CH}_{4}$ Flux and Respiration: Spatial and Temporal Variability Relationships to Temperature, Depth to Water Table and Ecological Grouping}

Mean $\mathrm{CH}_{4}$ flux was $42.8(n=259)$ and $20.1 \mathrm{mg} \mathrm{m}^{-2} \mathrm{~d}^{-1}(n=$ 406) for the 1995 and 1996 sampling periods, respectively (Table 2). The mean respiration was $5.1 \mathrm{~g}(n=385)$ and $3.2 \mathrm{~g}$ $\mathrm{CO}_{2} \mathrm{~m}^{-2} \mathrm{~d}^{-1}(n=406)$ for the respective years. There were similar trends in $\mathrm{CH}_{4}$ and respiration with respect to ecological groupings: $\mathrm{CH}_{4}$ flux increased from edges and hummocks to stream banks and lawns and pools (Table 3). Collars which included Sphagnum flexuosum, $S$. fallax, and $S$. torreyanum appeared to be associated with highest $\mathrm{CH}_{4}$ fluxes, repeating a pattern of bryophyte $-\mathrm{CH}_{4}$ flux correlations observed by Bubier et al. [1993, 1995] and others elsewhere. The respiration pattern was the reverse, where hummocks and edges showed higher $\mathrm{CO}_{2}$ fluxes than stream banks or pools. Highest respiration not only included associations of $S$. fallax and $S$. flexuosum in lawns, pools and banks, but also $S$. centrale, $S$. magellanicum, and $S$. imbricatum in edge and hummock areas.

Table 2. Seasonal mean and median $\mathrm{CH}_{4}$ flux and respiration during the two study years ${ }^{\mathrm{B}}$

\begin{tabular}{|c|c|c|c|c|}
\hline \multirow[b]{3}{*}{ Spring } & \multirow{2}{*}{\multicolumn{2}{|c|}{$\mathrm{CH}_{4}$ flux, $\mathrm{mg} \mathrm{m}^{-2} \mathrm{~d}^{-1}$}} & \multicolumn{2}{|c|}{ Resp., $\mathrm{g} \mathrm{CO}_{2} \mathrm{~m}^{-2} \mathrm{~d}^{-1}$} \\
\hline & & 1995 & \multicolumn{2}{|c|}{1996} \\
\hline & n.d. & $\begin{array}{l}16.3,4.1 \\
(110,-3)\end{array}$ & n.d. & $\begin{array}{l}4.2,2.6 \\
(119,-5)\end{array}$ \\
\hline Summer & $\begin{array}{r}65.2,21.9 \\
(166,-14)\end{array}$ & $\begin{array}{c}34.1,18 \\
2 \\
(165,-7)\end{array}$ & $\begin{array}{c}7.5,6.8 \\
(203,-15)\end{array}$ & $\begin{array}{l}4.1,3.6 \\
(202,-7)\end{array}$ \\
\hline Fall & $\begin{array}{l}2.7,1.3 \\
(93,-10)\end{array}$ & $\begin{array}{c}5.6,3.2 \\
(131,-3)\end{array}$ & $\begin{array}{c}2.5,2.1 \\
(182,-11)\end{array}$ & $\begin{array}{c}1.9,1.7 \\
(123,-4)\end{array}$ \\
\hline Overall & $\begin{array}{c}42.8,6.4 \\
(259,-13)\end{array}$ & $\begin{array}{l}20.1,6.1 \\
(407,-5)\end{array}$ & $\begin{array}{c}5.1,3.9 \\
(285,-13)\end{array}$ & $\begin{array}{l}3.2,2.6 \\
(444,-5)\end{array}$ \\
\hline
\end{tabular}

Figures in parentheses indicate the number of samples and mean depth to water table (centimeters). Abbreviation n.d., no data. 
Table 3. Mean and Median (In Parentheses) $\mathrm{CH}_{4}$ Flux and Respiration During the Two Study Years Across Ecological and Hydrological Groupings

\begin{tabular}{lcccccc}
\hline Ecological & \multicolumn{2}{c}{$\mathrm{CH}_{4}$ flux, $\mathrm{mg} \mathrm{m}^{-2} \mathrm{~d}^{-1}$} & \multicolumn{2}{c}{ Respiration, $\mathrm{g} \mathrm{CO}_{2}^{-2} \mathrm{~d}^{-1}$} & \multicolumn{2}{c}{ Depth to Water table, cm } \\
Group & 1995 & 1996 & 1995 & 1996 & 1995 & 1996 \\
\hline Hummock & $18.5,(3.2)$ & $6.6(2.7)$ & $5.2(3.8)$ & $3.9(3.6)$ & $-16.5(-14.8)$ & $-16.1(-15.4)$ \\
Lawn & $63.7,(8.0)$ & $28.0(4.8)$ & $5.2(4.0)$ & $3.4(2.8)$ & $-11.6(-12.0)$ & $-7.6(-7.2)$ \\
Bank & $27.4,(10.7)$ & $17.9(11.8)$ & $4.3(2.9)$ & $3.0(2.3)$ & $-10.4(-9.8)$ & $-3.5(-3.2)$ \\
Pool & n.d. & $37.2(8.0)$ & n.d. & $3.0(2.3)$ & n.d. & $2.5(1.5)$ \\
\hline
\end{tabular}

Abbreviation n.d., no data.

The largest $\mathrm{CH}_{4}$ fluxes and respiration occurred during the late spring and summer periods (Figure 2). Many sites also acted as $\mathrm{CH}_{4}$ sinks during the dry August and September of 1995. Respiration was higher in summer 1995 with a mean of $7.5 \mathrm{~g} \mathrm{CO}_{2} \mathrm{~m}^{-2} \mathrm{~d}^{-1}$, compared to $4.1 \mathrm{~g} \mathrm{CO}_{2} \mathrm{~m}^{-2} \mathrm{~d}^{-1}$ in 1996 (Table 2). During the fall period, fluxes of both gases were much reduced, with $\mathrm{CH}_{4}$ flux means in 1995 and 1996 of 2.7 and $5.6 \mathrm{mg} \mathrm{m}^{-2} \mathrm{~d}^{-1}$ respectively, and respiration means of 2.4 and $1.9 \mathrm{~g} \mathrm{CO}_{2} \mathrm{~m}^{-2} \mathrm{~d}^{-1}$, respectively. As it was drier in August and September 1995, the lowering of the water table increased the thickness of the oxic layer of the peat and thus increased the $\mathrm{CO}_{2}$ emissions. These types of results tend to show the nonlinearity of the temperature-soil moisture interaction, and will be discussed further below.

Relationships among $\mathrm{CH}_{4}$ flux, depth to water table, and peat temperature were weak for the individual point measurements, as has been noted elsewhere [e.g., Bubier et al., 1995;

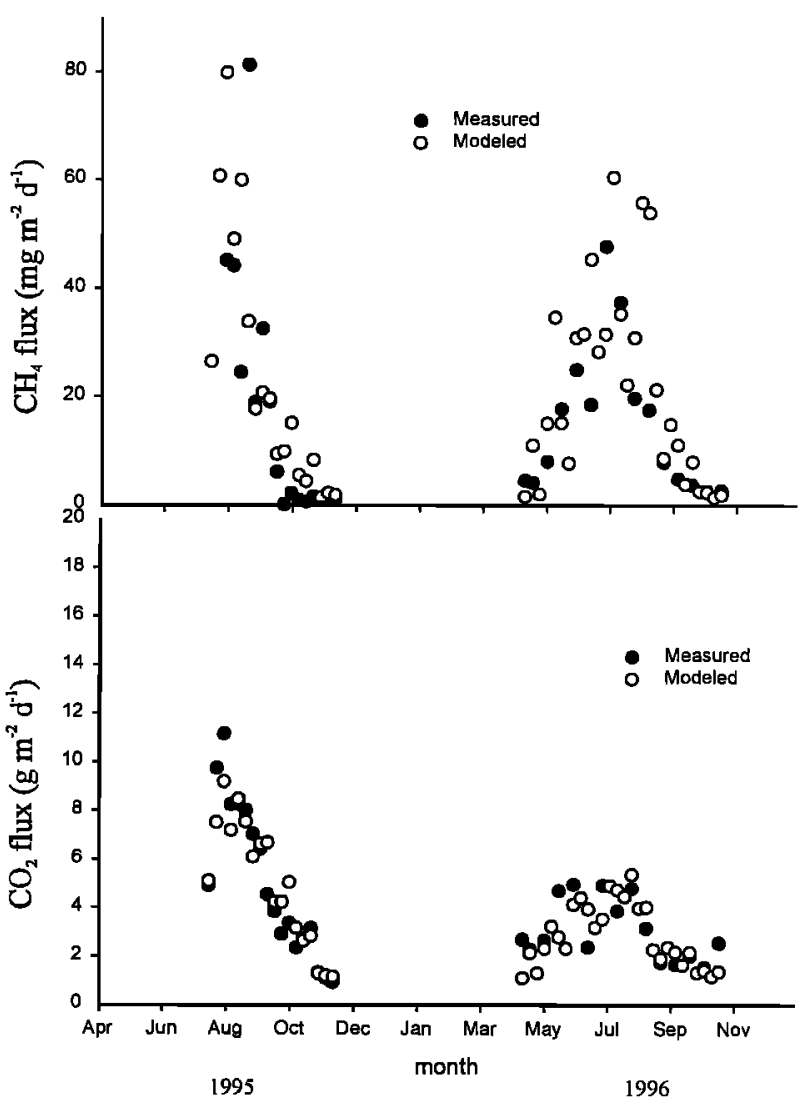

Figure 2. Comparison of weekly modeled versus measured values of (top) methane flux and (bottom) respiration at the study sites for the 1995-1996 seasons. The measured values are averaged. Standard deviations for $\mathrm{CH}_{4}$ flux averaged $+/-$ $15 \mathrm{mg} \mathrm{m}^{-2} \mathrm{~d}^{-1}$ (range $0.77-40$, median $5 \mathrm{mg} \mathrm{m}^{-2} \mathrm{~d}^{-1}$ ), and for respiration standard deviations averaged $2.3 \mathrm{~g} \mathrm{CO}_{2} \mathrm{~m}^{-2} \mathrm{~d}^{-1}$ (range 0.39-5.2, median $2.0 \mathrm{~g} \mathrm{CO}_{2} \mathrm{~m}^{-2} \mathrm{~d}^{-1}$ ).
Kettunen et al., 1996]. When $\mathrm{CH}_{4}$ data were pooled among sites, depth to water table and air temperature explained 41 and $30 \%$ of the variance in 1995 and 1996 , respectively. When data from both years were combined, $34 \%$ was explained (Table 4). In 1996, peat temperature at $15 \mathrm{~cm}$ depth rather than air temperature improved the $r^{2}$ from 0.30 to 0.37 . In each of these regressions, temperature played an important role in the explanation of $\mathrm{CH}_{4}$ flux variations and accounted for over $96 \%$ of the combined variance explanation.

In contrast to the individual measurements, average seasonal $\mathrm{CH}_{4}$ fluxes can, to some extent, be explained for each site by average depth to water table, as has been found for several other peatland regions in Canada [Liblik et al., 1997; Moore and Roulet, 1993]. For example, average depth to water table accounted for only $6 \%$ of the variation in $\mathrm{CH}_{4}$ flux in 1995 but accounted for $41 \%$ in 1996 . The weaker relationship in 1995 might be associated with the shorter sampling period and the greater flux rejection rates based on the sampling and data analysis protocol. The slopes of the 1995 and 1996 relationships with depth to water table $(=0.027$ and 0.048 , respectively) were similar to those observed in other regions, which ranged from 0.022 to 0.053 , with an average of 0.035 [Liblik et al., 1997].

The general relationship between average depth to water table and average $\mathrm{CH}_{4}$ flux is weakest when the water table is close to the surface. Under these conditions, vascular plant transport and other mechanisms leading to $\mathrm{CH}_{4}$ flux may override the relationship [Bellisario et al.,1999]. Subset examinations of average $\mathrm{CH}_{4}$ flux and average depth to water table suggested no significant increases in flux when the depth to water table is $<10 \mathrm{~cm}$. Overall, these results reveal a complex but predictable dependence of $\mathrm{CH}_{4}$ emissions on depth to water table and peat temperature. Here complexities are likely due to variations in diffusion pathways and lags, as discussed above.

Within-site variations of respiration were, on average, more strongly related to depth to water table and peat temperature than what was the case for the $\mathrm{CH}_{4}$ fluxes. Regression of antecedent depth to water table against respiration, however, did not improve the percentage of variance explained, suggesting a weak or nonexistent lag effect. Moore and Dalva [1993] found a similar weak hysteresis effect between $\mathrm{CO}_{2}$ flux and depth to water table from laboratory columns of peatland soils. This is probably because the lags occur in a matter of days, while the sampling occurred weekly, most likely missing a great deal of this factor.

Combining all measurements, depth to water table and air temperature explained 60 and $31 \%$ of the variation in respiration in 1995 and 1996, respectively, and $43 \%$ when both years of data were combined (Table 4). In contrast to the $\mathrm{CH}_{4}$ data, depth to water table was a more significant contributor to the explanation of the respiration variance, providing between 14 and $59 \%$ of the combined explanation. The incorporation of peat temperature in 1996 produced little improvement in predictive ability over daily air temperature, perhaps because part of the $\mathrm{CO}_{2}$ emitted from the soil is derived from root respiration, which is dependent on plant metabolic activities. In general, seasonal average respiration was positively related to depth to water table, with larger fluxes at sites with deeper water tables. In addition, $\mathrm{CO}_{2}$ fluxes increased with warmer temperatures, thereby producing a pronounced seasonal pattern. 
Table 4. Statistical Relationships Between $\mathrm{CH}_{4}\left(\mathrm{mg} \mathrm{m}^{-2} \mathrm{~d}^{-1}\right)$ Flux and Respiration $\left(\mathrm{g} \mathrm{CO}_{2} \mathrm{~m}^{-2} \mathrm{~d}^{-1}\right)$ and Depth to Water Table Depth (Dwt in $\mathrm{cm}$ ) and Air $\left(\mathbf{T}_{2}\right)$ or Peat Temperature $\left(\mathbf{T}_{10}, \mathbf{T}_{15}\right)$ in 1995 and 1996

1995 1996

Combined 1995 and 1996

\begin{tabular}{|c|c|c|c|}
\hline (a) & $\begin{array}{c}\log \left(\mathrm{CH}_{4}\right)=0.09 \mathrm{~T}_{\mathrm{e}}+0.01 \mathrm{DWT}-0.19 \\
r^{2}=0.41, n=259, p<0.001\end{array}$ & & \\
\hline (b) & & $\begin{array}{c}\log \left(\mathrm{CH}_{4}\right)=0.12 \mathrm{~T}_{15}+0.02 \mathrm{DWT}-0.65 \\
r^{2}=0.37, n=407, p<0.001\end{array}$ & \\
\hline (c) & $\begin{array}{c}\log \left(\mathrm{CO}_{2}\right)=0.05 \mathrm{~T}_{\mathrm{a}}-0.01 \mathrm{DWT}-0.13 \\
r^{2}=0.60, n=325, p<0.001\end{array}$ & & \\
\hline (d) & & $\begin{array}{c}\log \left(\mathrm{CO}_{2}\right)=0.02 \mathrm{~T}_{\mathrm{a}}-0.01 \mathrm{DWT}-0.001 \\
r^{2}=0.31, n=439, p<0.001\end{array}$ & \\
\hline (e) & & & $\begin{array}{c}\log \left(\mathrm{CH}_{4}\right)=0.08 \mathrm{~T}_{\mathrm{a}}+0.02 \mathrm{DWT}-0.02 \\
r^{2}=0.34, n=666, p<0.001\end{array}$ \\
\hline (f) & & & $\begin{array}{c}\log \left(\mathrm{CO}_{2}\right)=0.03 \mathrm{~T}_{\mathrm{a}}-0.015 \mathrm{DWT}-0.1 \\
r^{2}=0.43, n=824, p<0.001\end{array}$ \\
\hline (g) & & & $\begin{array}{c}\log \left(\mathrm{CH}_{4}\right)=0.92-0.068 \log \left(\mathrm{CO}_{2}\right) \\
r^{2}=0.001, n=666, p=0.386\end{array}$ \\
\hline
\end{tabular}

\subsection{Regional Modeling of $\mathrm{Ch}_{4}$ Flux and Respiration}

To simplify the linkages between soil moisture and temperature, and in order to produce a regional as opposed to sitespecific approach, we averaged daily respiration and $\mathrm{CH}_{4}$ fluxes from each site per sampling day for both 1995 and 1996. We then correlated the mean gas fluxes with the modeled regional forest soil moisture and temperature as computed with ForHyM2 [Meng et al., 1995]. We experimented with a number of possible regressions and arrived at the following optimized relationships by trial and error:

$$
\begin{aligned}
& \begin{aligned}
\mathrm{CH}_{4}\left(\mathrm{mg} \mathrm{m}^{-2} \mathrm{~d}^{-1}\right) & =\exp \left(0.956 \mathrm{~T}_{\mathrm{MB}}-0.066 \text { soil moisture }\right) \\
r^{2} & =0.65 ; n=33 ; p<0.001
\end{aligned} \\
& \begin{array}{c}
\mathrm{CO}_{2}\left(\mathrm{~g} \mathrm{~m}^{-2} \mathrm{~d}^{-1}\right)=\exp \left(0.306 \mathrm{~T}_{\mathrm{MB}}-0.012 \text { soil moisture }\right) \\
r^{2}=0.80 ; n=33, p<0.001
\end{array}
\end{aligned}
$$

where $\mathrm{CH}_{4}$ and $\mathrm{CO}_{2}$ represent sampling daily flux averages, soil moisture refers to ForHyM2 simulated soil moisture content of the rooted forest soil (forest floor plus mineral A and $B$ soil horizons), and $T_{M B}$ refers to simulated soil temperatures midway within the B soil. Simulated temperatures for this soil horizon generated the best results in comparison with regressions done with air temperature, water table level, and temperatures in the $\mathrm{O}, \mathrm{A}$ and $\mathrm{C}$ layers as independent variables.

Since (1) and (2) are quite similar, it follows that $\mathrm{CH}_{4}$ emissions can also be estimated from the $\mathrm{CO}_{2}$ emissions. The following regression equation was obtained:

$$
\begin{aligned}
\mathrm{CH}_{4} & \left(\mathrm{mg} \mathrm{m}^{-2} \mathrm{~d}^{-1}\right)=6.79 \mathrm{CO}_{2}\left(\mathrm{~g} \mathrm{~m}^{-2} \mathrm{~d}^{-1}\right) \\
r^{2} & =0.65 ; n=33 ; p<0.001 .
\end{aligned}
$$

Estimating the $\mathrm{CH}_{4}$ emission rate in this way is, however, inferior in comparison to estimating the same rate independently of the $\mathrm{CO}_{2}$ emission rate because of error propagation. Notice that this relationship is also not sustained when examined in detail by regressing all $\mathrm{CH}_{4}$ and $\mathrm{CO}_{2}$ flux observations (Table 4, equation g). Obviously, $\mathrm{CH}_{4}$ flux and respiration are not directly related to one another on the small scale, presumably because of strong spot changes from aerobic to anaerobic conditions and vice versa. Spatial averaging across the wetland, however, makes it appear that way, because both fluxes do respond to the prevailing temperature conditions at the same time.

Calculated water tables were generally related to the field observed average depth to water table. This relationship was nonlinear, that is, field observed water table leveled off with increasing values of predicted water table height, as shown by the following equation:

$$
\begin{aligned}
& \text { Water table height }(\mathrm{cm})= \\
& 15-0.78 \text { exp }[-3.36 \text { predicted height }(\mathrm{cm})] \\
& \mathrm{r}^{2}=0.88 ; n=33 ; p<0.001 .
\end{aligned}
$$

Here the observed water table height is negative once the water table drops below an arbitrarily chosen reference level. This leveling off reflects the fact that water, as it rises above the low sections of the wetland, will be more rapidly drained from the bog. In ForHyM2, all water table calculations assume that the water is totally confined within the subsoil.

Overall, the regional $\mathrm{CH}_{4}$ flux and respiration regressions emphasize the importance of soil temperature in determining gas production directly, by way of $\mathbf{T}_{\mathrm{MB}}$, and indirectly (cumulatively) by way of the negative dependence on the soil moisture level. To illustrate this result, we note that the wetland-wide $\mathrm{CH}_{4}$ fluxes and respiration are the lowest when soil moisture levels are generally high throughout the uplands and wetlands, and when soil temperatures are cool at the same time. This generally occurs at the beginning and at the end of each growing season. However, the period of greatest $\mathrm{CH}_{4}$ flux and respiration occurs in midyear when soil water table is receding and when soils are warm.

When comparing the measured field data with the modeled results for respiration and $\mathrm{CH}_{4}$ fluxes over the 1995 and 1996 sampling seasons (Figures 2 and 3 ), two points became obvious. First, using a regional soil moisture model did not reduce our predictive capacity. Using both years' data, and using site-specific information for $\mathrm{CH}_{4}$, our regression model based on individual sampling points only explained $34 \%$ of the variability (Table 4 ), compared to $65 \%$ using the dayaveraged values and the modeled soil moisture and temperature predictions. Using the site-specific respiration produced a regression explaining $43 \%$ of the flux variability, while the regression based on the regional, averaged data explained $80 \%$ (equation 2).

Second, there is more uncertainty with measuring and calculating $\mathrm{CH}_{4}$ fluxes than respiration, which is directly related to the high variability of the $\mathrm{CH}_{4}$ emissions. Overall, we feel that (1) and (2) can be used for modeling region-wide, growthseason respiration and $\mathrm{CH}_{4}$ fluxes. Region-wide estimates can be obtained by multiplying the existing wetland areas with the daily numbers to be produced by way of (1) and (2). To move from one region to the other, (1) and (2) can still be used (assuming similar bog topography), but it will be necessary to reevaluate the local soil moisture and temperature conditions by way of the region-specific ForHyM2 output. 

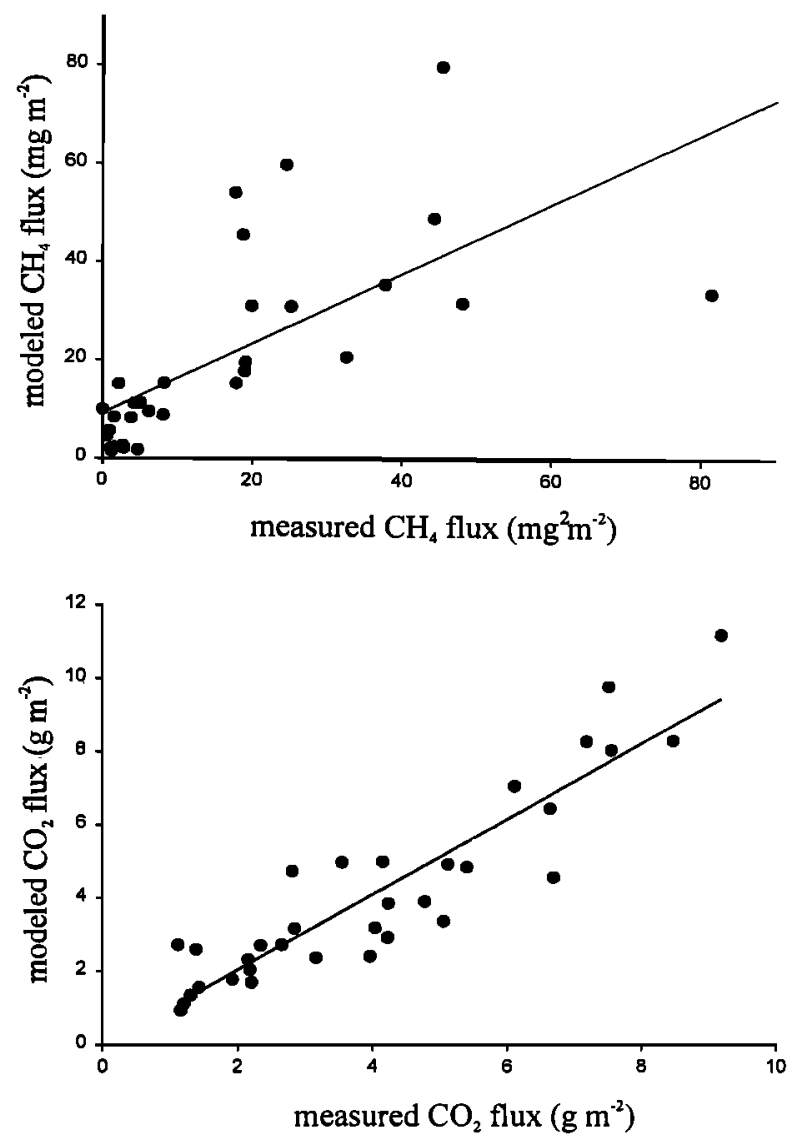

Figure 3. Modeled fluxes versus average measured values with regression lines for (top) $\mathrm{CH}_{4}$ and (bottom) respiration.

The data generated by this model can be used in a number of different ways. First, the area flux estimates can be applied to the whole wetland by simply multiplying the area averaged modeled results by the wetlands's surface area. This provides some idea of local fluxes in a marine-influenced region. Expansion of this approach within the wetlands of this ecoregion (southern Nova Scotia) will give some idea of largescale fluxes in this region, although an estimate of total wetland surface area is not yet available.

\subsection{Predicting $\mathrm{Ch}_{4}$ Flux and Respiration Over Time}

To estimate the variability in gas fluxes driven by variations in temperature and precipitation over a longer period of time, $\mathrm{CH}_{4}$ and respiration were calculated for the May to October periods from 1966 to 1998 , using the daily data collected at the weather site (Figure 4) and (1) and (2). From this we estimated that over the 32 year period the average growing season $\mathrm{CH}_{4}$ flux was $3.7 \mathrm{~g} \mathrm{~m}^{-2}$, with a standard deviation of 1.2 $\mathrm{g} \mathrm{m}^{-2}$. The average respiration was $0.74 \mathrm{~g} \mathrm{CO}_{2} \mathrm{~m}^{-2}$ with a standard deviation of $0.11 \mathrm{~g} \mathrm{CO}_{2} \mathrm{~m}^{-2}$. The lowest estimated $\mathrm{CH}_{4}$ flux was $1.72 \mathrm{~g} \mathrm{~m}^{-2}$ for the cool and wet growing season of 1974. The highest $\mathrm{CH}_{4}$ flux estimate of $10.49 \mathrm{~g} \mathrm{~m}^{-2}$ was generated for 1998 , the warmest sunmer on record. These data clearly show that we should expect large interannual $\mathrm{CH}_{4}$ flux and soil and plant community respiration variations in eastern Canadian wetlands. On a long-term basis, Figure 4 also shows the tight relationship between air temperature and Greehouse Gas (GHG) fluxes in these wetlands. Precipitation plays a role, but it is clearly secondary.

Using a process-based model to calculate $\mathrm{CH}_{4}$ production, consumption, and transport rates in relation to climate drivers such as daily air temperature, precipitation, snow depth and depth to water table, Granberg et al. [1997; Effects of climatic variability from 1980 to 1997 on methane emissions from a boreal mire in northern Sweden, manuscript in preparation,2000] calculated the annual $\mathrm{CH}_{4}$ flux of a lawn community in a Swedish mire. For the period 1980-1997 these authors estimate an annual $\mathrm{CH}_{4}$ emission rate of $14 \mathrm{~g} \mathrm{~m}^{-2}$, with a range of 6 to $32 \mathrm{~g} \mathrm{~m}^{-2}$ and a standard deviation of $7 \mathrm{~g}$ $\mathrm{m}^{-2}$. This interannual variability in $\mathrm{CH}_{4}$ emissions is similar to ours.

To quantify the effect of a proposed climatic change on gas emissions, we recomputed the estimate emission rates of $\mathrm{CH}_{4}$ and respiration by modifying the 1992-1998 meteorological record to reflect the air temperature and precipitation anomalies predicted by the GCM outputs, as described above. We then used the modified data as input to the regional $\mathrm{CH}_{4}$ and $\mathrm{CO}_{2}$ production models (equations (1) and (2)), and recalculated the gas fluxes accordingly. Our calculations show that for the May to October period, $\mathrm{CH}_{4}$ emission rates should more than double, from an average of 4.7 to $11.4 \mathrm{~g} \mathrm{~m}^{-2}$ (Figure 5). Similarly, predicted respiration would increase by $71 \%$, from averages of 7.7 to $13.2 \mathrm{~kg} \mathrm{CO}_{2} \mathrm{~m}^{-2}$ (Figure 5).

Note that the GCMs do not predict a large change in precipitation during the growing season in the region. However, under the increase in temperature, the soil model predicts that moisture will decrease, thereby leading to increased aerobic conditions in wetland soils. Intuitively, this should lead to increased respiration of $\mathrm{CO}_{2}$ and decreased emission of $\mathrm{CH}_{4}$. However, the temperature dependence of microbial $\mathrm{CH}_{4}$ consumption is weak, with $\mathbf{Q}_{10}$ values of less than 2 [e.g., Dunfield et al., 1993]. In contrast, respiration by soils shows a modest dependence on temperature, with $\mathbf{Q}_{10}$ values in the range 2 to 3 [Moore and Dalva, 1993; Silvola et al., 1996]. Measurements of $\mathrm{CO}_{2}$ production from roots frequently show a very strong dependence on temperature, with $Q_{10}$ values as high as 4 [Boone et al., 1998].

We caution that the predicted changes can only be expected under stable vegetation patterns. For example, long-term changes in temperature and hydrological regimes will lead to changes in wetland types and thus changes in respiration and $\mathrm{CH}_{4}$ emission rates. Recent work on runoff in the region [Clair et al., 1998] suggests that spring flood conditions should occur one month earlier than what is now the case and that summer droughts will occur 1 month longer than at
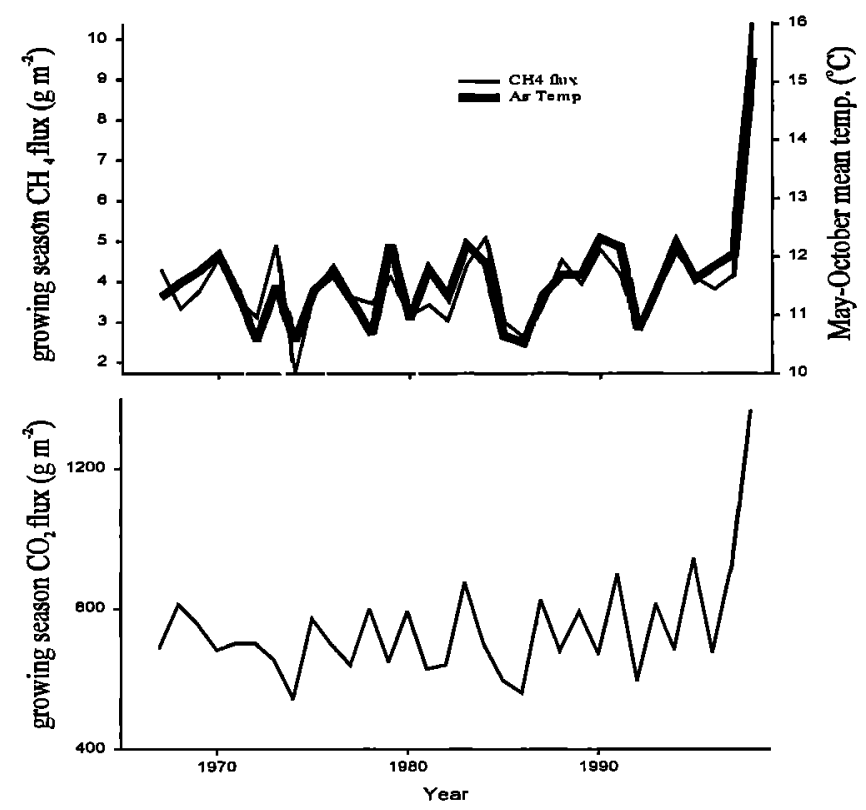

Figure 4. (top) Modeled May to October $\mathrm{CH}_{4}$ flux and (bottom) $\mathrm{CO}_{2}$ from 1966 to 1998 based on climatic inputs. Growing season average temperature is overlying the total modeled $\mathrm{CH}_{4}$ fluxes. 
May-October $\mathrm{CO}_{2}$ prod. $\left(\mathrm{kg} \mathrm{m}^{-2}\right)$

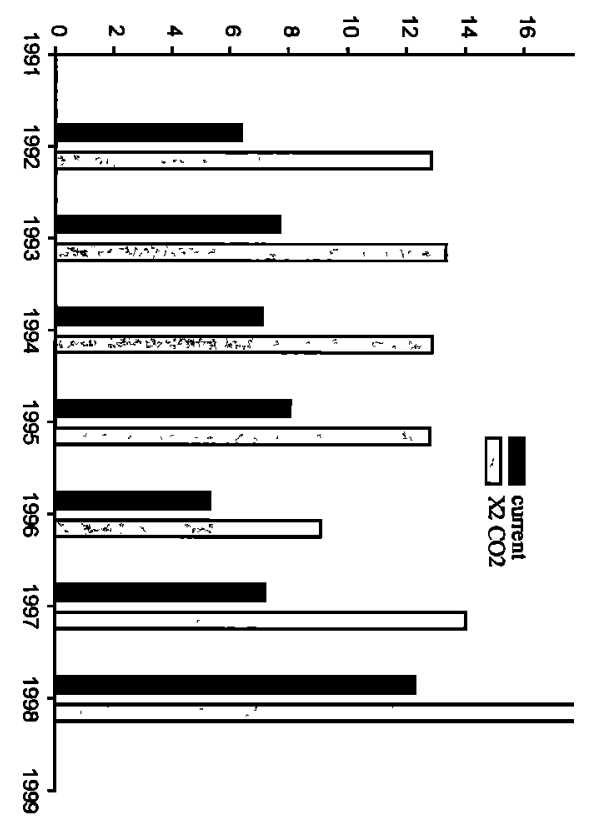

May-October $\mathrm{CH}_{4}$ prod. $\left(\mathrm{g} \mathrm{m}^{-2}\right)$

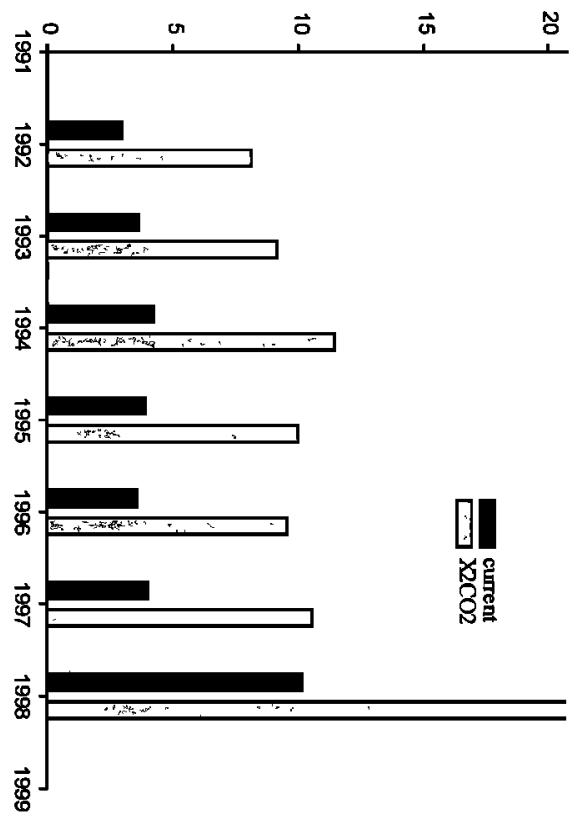

Figure 5. Estimated May to October $\mathrm{CH}_{4}$ flux and res])iration under current (dark bars) and predicted $2 \times \mathrm{CO}_{2}$ (light bars) conditions.

present. Such major hydrological changes will undoubtedly cause ecological changes which will have an impact on peat formation and decomposition and thus on gas fluxes. However, we feel that our results produce a good first estimation of the changes to be expected, at least during a transition period between current and future wetland communities.

\section{Conclusions}

Our field results clearly indicate how wetland $\mathrm{CH}_{4}$ emissions and soil and plant community respiration are driven by microtopographical, hydrological, and biological conditions in the wet and cool temperate regions of North America. Despite the spatial heterogeneity in both water table movements and gas fluxes, we found that a regional soil moisture model provided a good simulation of wetland $\mathrm{CH}_{4}$ emission and respiration at the site that we were studying.

Application of both the $\mathrm{CH}_{4}$ and respiration models revealed that we should expect a great deal of year-to-year variation in the emission of both gases. Our results suggest that from 1966 to $1997, \mathrm{CH}_{4}$ fluxes ranged from approximately 2 to $5 \mathrm{~g} \mathrm{~m}^{-2}$ during the growing season. For the unusually warm summer of 1998 , calculated $\mathrm{CH}_{4}$ fluxes are twice as high as the maximum rates of the preceding 32 years.

For the case of the CCC GCMII climate inputs, we predict that the $\mathrm{CH}_{4}$ fluxes will more than double from current rates and that respiration will increase by slightly less than double. We have not yet evaluated whether these types of increases would be sustainable over the long term. In addition, a longterm change in climate would suggest that major changes in wetland soil conditions would occur over time.

Acknowledgments. The authors thank Floyd Luxton for his dedicated field sampling over the course of the study. Staff and management at Kejimkujik National Park provided excellent moral and logistical support to the study team.

\section{References}

Allen, Y., T.A. Clair, B. Freedman, and W. Maas, Hydrogeochemistry and biophysical description of the Pine Marten Brook study area,
Kejimkujik National Park, Tech. Rep. WRD-AR-MEB-92 181,34pp., Environ. Can.-Atl. Reg., Moncton, New Brunswick, 1992.

Alm, J., S. Saamio , H. Nykanen, J. Silvola, and P.J. Martikainen, Winter $\mathrm{CO}_{2}, \mathrm{CH}_{4}$ and $\mathrm{N}_{2} \mathrm{O}$ fluxes on some boreal natural and drained peatlands, Biogeochemistry, 44, 163-186, 1999.

Bellisario, L.M., J.L. Bubier, J. Chanton, and T.R. Moore, Controls on $\mathrm{CH}_{4}$ emissions from a northern peatland, Global Biogeochem. Cycles, 13, 81-92, 1999.

Boer, G.J., N.A. McFarlane, and M. Lazare, Greenhouse gas-induced climate change simulated with the CCC second-generation general circulation model, J. Clim., 5, 1045-1077, 1992

Boone, R.D., K.J. Nadelhoffer, J.D. Canary, and J.P. Kaye, Roots exert a strong influence on the temperature sensitivity of soil respiration, Nature, 396, 570-572, 1998.

Bubier, J.L., and T.R. Moore, An ecological perspective on methane emissions from northern wetlands, TREE, 9, 460-464, 1994.

Bubier, J.L., T.R. Moore, and S. Juggins, Predicting methane emission from bryophyte distribution in northern Canadian peatlands, Ecology, 74, 2240-2254, 1993.

Bubier, J.L., T.R. Moore, L. Bellisario, and N.T. Comer, Ecological controls on methane emisssions from a northern peatland complex in the zone of discontinuous permafrost Manitoba, Canada Global Biogeochem. Cycles, 9, 455-470, 1995.

Cao, M., K. Gregson and S. Marshall, Global methane emission from wetlands and its sensitivity to climatic change, Atmos. Environ. 32, 3293-3299, 1998

Clair, T.A., J. Ehrman, and K. Higuchi, Changes to the runoff of Canadian Ecozones under a doubled $\mathrm{CO}_{2}$ atmosphere, Can. J. Fish. Aquat. Sci., 55, 2464-2477, 1998.

Dunfield, P., R. Knowles, R. Dumont, and T.R. Moore, Methane production and consumption in temperate and subarctic peat soils: Response to temperature and $\mathrm{pH}$, Soil Biol. Biochem., 23,321-326, 1993.

Fung, I., J. John, J. Lerner, E. Matthews, M. Prather, L.P. Steele, and P.J. Fraser, Three-dimensional model synthesis of the global methane cycle, J. Geophys. Res., 96(D7) 13.033-13,065, 1991.

Gorham, E., The role of northern peatlands in the carbon cycle, and their probable response to climate warming, Ecol. Appl., $I, 182-$ $195,1991$.

Granberg, G., C. Mikkela, I. Sundh, B.H. Svensson, and M. Nilsson, Sources of spatial variation in methane emission from mires in northern Sweden: A mechanistic approach in statistical modeling, Global Biogeochem. Cycles, 11, 135-150, 1997.

Kettunen, A., V. Kaitala, J. Alm, J. Silvola, H. Nykannen, and P.J. Martikainen, Cross-correlation analysis of the dynamics of methane emissions from a boreal peatland, Global Biogeochem. Cycles, 10,457-471, 1996.

Liblik, L.K., T.R. Moore, J.L. Bubier, and S.D. Robinson, Methane emissions from wetlands in the zone of discontinuous permafrost: Fort Simpson, Northwest Territories, Canada, Global Biogeochem. Cycles, 11, 485-494, 1997. 
Meng, F.-R., C. Bourque, K. Jewett, D. Daugharty, and P.A. Arp, The Nashwaak experimental watershed project: Analysing effects of clearcutting on soil temperature, soil moisture, snowpack, snowmelt and stream flow, Water Air Soil Pollut., 82, 363-374, snowm.

Moore, T.R., and M. Dalva, Influence of temperature and water table position on carbon dioxide and methane emissions from laboratory columns of peatland soils, J. Soil Sci. 44, 651-664, 1993.

Moore, T.R., and N.T. Roulet, Methane flux and water table relations in northern wetlands, Geophys. Res. Lett., 20, 587-590, 1993.

Moore, T.R., N.T. Roulet, and J.M. Waddington, Uncertainty in predicting the effect of climatic change on the carbon cycling of Canadian peatlands, Clim. Change, 40, 229-245, 1998.

Raich, J.W., and S.C. Potter, Global patterns of carbon dioxide emissions from soils, Global Biogeochem. Cycles, 9, 23-36, 1995.

Roulet, N., T. Moore, J. Bubier, and P. Lafleur, Northern fens: Methane flux and climatic change, Tellus, 44B, 100-105, 1992.

Silvola, J., J. Alm, U. Ahlholm, X. Nykänen, and P.J. Martikainen, The contribution of plant roots to $\mathrm{CO}_{2}$ fluxes from organic soils, Biol. Fert. Soils, 23,126-131, 1996.
Waddington, J.M., and N.T. Roulet, Atmosphere-wetland carbon exchanges: Scale dependency of $\mathrm{CO}_{2}$ and $\mathrm{CH}_{4}$ exchange on the developmental topography of a peatland, Glabal Biogeochem. Cycles, 10, 233-245, 1996.

P. Arp, Faculty of Foresty and Environmental Manageinent, University of New Brunswick, Fredericton, New Brunswick, Canada E3B 6C2.

T.A. Clair, Environment Canada-Atlantic Region, P.O. Box 6227, Sackville, New Brunswick, Canada E4L $1 \mathrm{G} 6$

M. Dalva and T.R. Moore, Department of Geography and Centre for Climate and Global Change Research, McGili University, 805 Sherbrooke St. W., Montréal, Québec, Canada H3A 2K6.

(Received November 18, 1999; revised July 25, 2000; accepted August 10, 2000.) 